\title{
Pneumonia stafilococică, o provocare actuală în practica pediatrică - prezentare de caz
}

\author{
Nicoleta-Ana Tomșa ${ }^{1}$, Lorena Elena Meliț1,2, Gabriela Bucur', Iunius Simu²,3, \\ Bianca Aron ${ }^{1}$, Cristina Oana Mărginean ${ }^{1,2}$ \\ ${ }^{1}$ Clinica Pediatrie, Spitalul Clinic Judeţean de Urgenţă, Tg. Mureş, România \\ 2Universitatea de Medicină şi Farmacie, Ştiinţe şi Tehnologie „G.E. Palade", \\ Tg. Mureş, România \\ ${ }^{3}$ Clinica Radiologie şi Imagistică Medicală, Spitalul Clinic Judeţean de Urgenţă, \\ Tg. Mureş, România
}

\begin{abstract}
REZUMAT
Introducere. Aproximativ 12 milioane de copii mor anual în țările în curs de dezvoltare, iar o treime din aceste decese sunt cauzate de pneumonii. Evaluarea modificărilor radiologice în dinamică are un rol major în stabilirea diagnosticului de pneumonie stafilococică.

Scopul lucrării este de a sublinia dificultățile de diagnostic și tratament într-un caz de pneumonie stafilococică la copil.

Prezentarea cazului. Prezentăm cazul unui pacient, de sex masculin, în vârstă de 2 ani și 6 luni, internat în clinica noastră pentru hiperpirexie, tuse productivă, rinoree și inapetență. Examenul clinic la internare a pus în evidență stare generală influențată, facies palid, suferind, febră, tuse productivă, rinoree, murmur vezicular diminuat pe partea dreaptă, saturație în oxigen $97 \%$, și inapetență, iar analizele de laborator leucocitoză marcată cu neutrofilie, anemie și markeri inflamatori intens crescuți. Radiografia toracică a pus în evidență un focar congestiv la nivelul lobului inferior drept. Hemocultura a fost negativă. S-a inițiat tratament simptomatic și antibiotic (Ceftriaxonă), dar datorită evoluției nefavorabile, radiografia de control a arătat o zonă de condensare bazal drept asociind o colecție pleurală închistată bazal și laterotoracic drept. Am efectuat și computer tomografie (CT) toracică, evidențiindu-se un proces pneumonic bisegmentar în lobul inferior drept, cu câteva pneumatocele grupate subpleural, asociind în ambii plămâni arii de hiperinflație lobulară. Astfel, se ridică suspiciunea unei pneumonii verosimil stafilococice, motiv pentru care se asociază Vancomicină iv, cu evoluție favorabilă.

Concluzii. Pneumonia stafilococică este o patologie bine definită şi cunoscută în literatură, dar rămâne totuşi o patologie contemporană, impunând multiple dificultăţi legate de diagnosticul şi managementul cazurilor pediatrice.
\end{abstract}

Cuvinte cheie: copil, pneumonie, S. aureus, evaluare imagistică

\section{INTRODUCERE}

Staphylococcus aureus (S. aureus) a fost descris pentru prima dată în 1800 ca o cauză a sepsisului și a abceselor. Din punct de vedere microbiologic, este o bacterie gram-pozitivă, sub formă de coci, care au tendinţă de a se aduna în grupuri sub forma unor ciorchine de struguri, de culoare galbenă; aceste microorganisme putând creşte atât în mediu aerob cât şi anaerob, la temperaturi cuprinse între 18 şi 40 grade C.
În laboratoarele de specialitate se folosesc medii de cultură speciale pentru a diferenţia speciile de $S$. aureus de celelalte specii $(1,2,3)$. S. aureus cauzează cel mai frecvent infecţii la nivelul tegumentului, dar este implicat atât în infecțiile căilor aeriene inferioare (pneumonii), cât şi în infecții din sfera cardiacă endocardite, sau ale țestutului osos-osteomielite $(1,4)$. Portajul nazal este definit prin prezența acestei bacterii în cavitatea nazală, existând la aproximativ $30 \%$ din populație. Transmiterea se realizează de la 
persoană la persoană, dar şi prin obiecte contaminate, mai rar prin tuse sau strănut. Bacteriile şi viruşii fac parte din flora bacteriană normală a căilor aeriene atât superioare cât și inferioare. Un mecanism al dezvoltării pneumoniilor este replicarea acestor microorganisme deja existente la acest nivel, alt mecanism fiind legat de incompetența sistemului imunitar al gazdei $(1,2)$. Atunci când ne referim la $S$. aureus, este esențial să delimităm cele 2 entităţi $S$. aureus meticilino-sensibil (MSSA), respectiv meticilino-rezistent (MRSA), acestea determinând strategia terapeutică ulterioară $(2,3)$.

Pneumonia stafilococică a fost descrisă pentru prima dată în 1919 în timpul pandemiei de gripă, iar datele de la copiii cu pneumonie stafilococică au fost colectate pentru prima dată între anii 1950-1960 în Europa și America de Nord $(5,6)$. Se estimează că aproximativ 12 milioane de copii mor anual în țările în curs de dezvoltare, iar o treime din aceste decese sunt cauzate de pneumonii, frecvent determinate de Streptococcus pneumoniae și Haemophilus influenzae, S. aureus fiind implicat în 5-10\% din etiologia acestora $(6,7)$. Este o patologie severă, întâlnită cel mai frecvent la sugar și copilul mic, având o mortalitate de $12-15 \%(1,8)$.

Diagnosticul pneumoniei stafilococice începe prin evaluarea pacientului putând pune în evidență stare generală alterată, hiperpirexie, tuse productivă, rinoree, inapentență, dureri abdominale, vărsături şi tranzit intestinal accelerat $(5,6)$. Analizele de laborator arată leucocitoză cu neutrofilie, anemie și markeri inflamtori crescuți. Hemocultura este esențială pentru stabilirea certă a etiologiei, însă acestea sunt pozitive doar în $20-40 \%$ din cazuri (5). Standardul de aur însă pentru penumonie rămâne evaluarea imagistică, radiografia toracică, căreia în ultima perioadă i-a luat locul ultrasonografia toracică $(9,10)$. Este foarte important de precizat faptul că examenul radiologic, în pneumonia suspectată a fi stafilococică, trebuie realizat în dinamică, putând evidenţia infiltrat lobular sau leziuni cavitare până la empiem. În cazul în care radiografia toracică nu elucidează complet diagnosticul, atunci rămâne indicația de efectuare a unei tomografii computerizate (CT), care ne poate pune în evidență cu precizie mult mai mare infiltratele lobulare sau leziunile existente la nivel pulmonar (10).

Managementul pneumoniei stafilococice se bazează atât pe tratamentul simptomatic dar mai ales pe cel etiologic, care în formele uşoare şi medii implică monoterapie cu Vancomicină sau Oxacilină in- travenos (iv), în formele severe fiind nevoie însă de asocieri de antibiotice cum ar fi Vancomicina și Oxacilina sau Gentamicina la cele meticilino-rezistente $(1,5)$. În formele care asociază revărsat pleural masiv este nevoie de tratament chirurgical cu drenajul extern al lichidului pleural. Evoluția și prognosticul acestei afecțiuni sunt imprevizibile, fiind o boală severă, grevată de comorbidităţile pacientului, o evoluție trenantă și o rată mare de mortalitate (5).

Scopul lucrării este de a sublinia dificultățile de diagnostic și tratament într-un caz de pneumonie stafilococică la copil.

\section{PREZENTAREA CAZULUI}

\section{Motivele internării}

Prezentăm cazul unui pacient, de sex masculin, în vârstă de 2 ani și 6 luni, născut prematur la 33-34 săptămâni gestaționale, internat în clinica noastră pentru hiperpirexie, tuse productivă, rinoree și inapetență. Menționăm că debutul simptomatologiei a fost cu 6 zile anterior prezentării, fiind tratat ambulator cu antibiotic și simptomatice, însă fără ameliorare.

\section{Examen obiectiv}

Examenul clinic la internare a pus în evidență stare generală influențată, facies palid, suferind, febră $\left(38,8^{\circ} \mathrm{C}\right)$, tuse productivă, rinoree, murmur vezicular diminuat pe partea dreaptă, saturație în oxigen $97 \%$, și inapetență. Greutatea pacientului a fost de $11 \mathrm{~kg}$.

\section{Elemente de diagnostic și evaluare}

Analizele de laborator efectuate la internare au pus în evidență leucocitoză marcată $\left(21.120 / \mathrm{mm}^{3}\right) \mathrm{cu}$ neutrofilie (72\%), hemoglobina uşor scăzută (Hgb $10,5 \mathrm{~g} / \mathrm{dl}$ ), markeri inflamtori intens crescuți (proteina C-reactivă - PCR 107 mg/1 și viteza de sedimentare a hematiilor - VSH $80 \mathrm{~mm} / \mathrm{h}$ ). Radiografia toracică a pus în evidență un focar congestiv la nivelul lobului inferior drept (Figura 1). S-a recoltat, de asemenea, și hemocultură, al cărei rezultat a fost negativ. S-a iniţiat tratament simptomatic şi antibiotic (Cefritaxona iv) cu evoluție ușor favorabilă. După aproximativ 72 de ore de la internare, starea pacientul s-a agravat, cu reapariția febrei, analizele de laborator menținându-se modificate (leucocite $10,250 / \mathrm{mm}^{3}$, neutrofile $24 \%$, PCR $73,1 \mathrm{mg} / \mathrm{l}$, VSH: $41 \mathrm{~mm} / \mathrm{h}$ ), motiv pentru care s-a decis reevaluarea radiologică, 


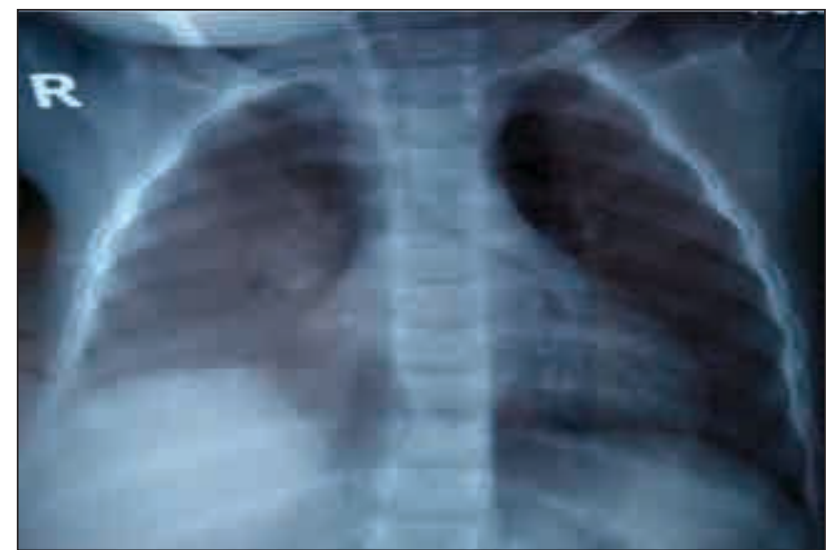

FIGURA 1. Radiografia pulmonară la internare - focar congestiv lob inferior drept

care a arătat o zonă de condensare bazal drept asociind o colecție pleurală închistată bazal și laterotoracic drept. Am efectuat și CT toracică la recomandarea medicului chirurg pediatru, evidențiindu-se un proces pneumonic bisegmentar în lobul inferior drept (lateral și posterior) cu bronhogramă aeriană, cu câteva pneumatocele grupate subpleural, asociind în ambii plămâni arii de hiperinflație lobulară (Figura 2). Pe baza tuturor elementelor din anamneză, examen clinic, evoluția ondulantă a bolii și elemetele de laborator se ridică suspiciunea unei pneumonii verosimil stafilococice.

\section{Conduita terapeutică, monitorizare și evoluție}

Am asociat Vancomicinei iv tratament antipiretic (Paracetamol) și perfuzie de rehidratare. $\mathrm{Cu}$ tratamentul instituit, evoluția pacientului a fost favorabilă, cu ameliorarea stării generale, dispariția croșetelor febrile, reluarea apetitului alimentar, normalizarea datelor de laborator (leucocite 6.210/mm3, Hgb 11,6 $\mathrm{g} / \mathrm{dl}$, PCR $1,77 \mathrm{mg} / \mathrm{l})$, iar radiografia de control efectuată la 2 săptămâni de la episodul infecțios a pus în evidență o zonă de atelectazie segmentară/subsegmentară dreaptă.

\section{DISCUȚII}

Pneumonia și malnutriţia sunt 2 dintre cele mai mari cauze de mortalitate în copilărie (11). S. aureus este omniprezent atât în mediu urban, cât și în cel rural. Caracteristicile de virulență ale $S$. aureus (şi anume imunogenitatea slabă, necrotizarea, toxigenicitatea complexă, rezistența antimicotică, capacitatea de a metastaza și de a scăpa de fagocitoză) și funcția neutrofilelor suprimată temporar de o infecție virală din antecedente sunt responsabile de o boală severă la toate grupele de vârstă cu imunitate celulară şi umorală normală $(12,13)$. În cazul pacientului nostru nu am identificat o patologie virală în antecedente, iar evoluția a fost favorabilă după introducerea antibioterapiei de elecție pentru S. aureus. Aproximativ jumătate dintre copiii cu bacteriemie stafilococică pot avea o boală diseminată. Cu toate acestea, datele recente din literatura de specialitate se limitează doar la prezentări de caz izolate (14-16), iar patologia apare cel mai frecvent la copiii anterior sănătoși, din grupa de vârstă 5-10 ani (16,17). Sexul masculin este mai frecvent afectat decât sexul feminin, reflectând
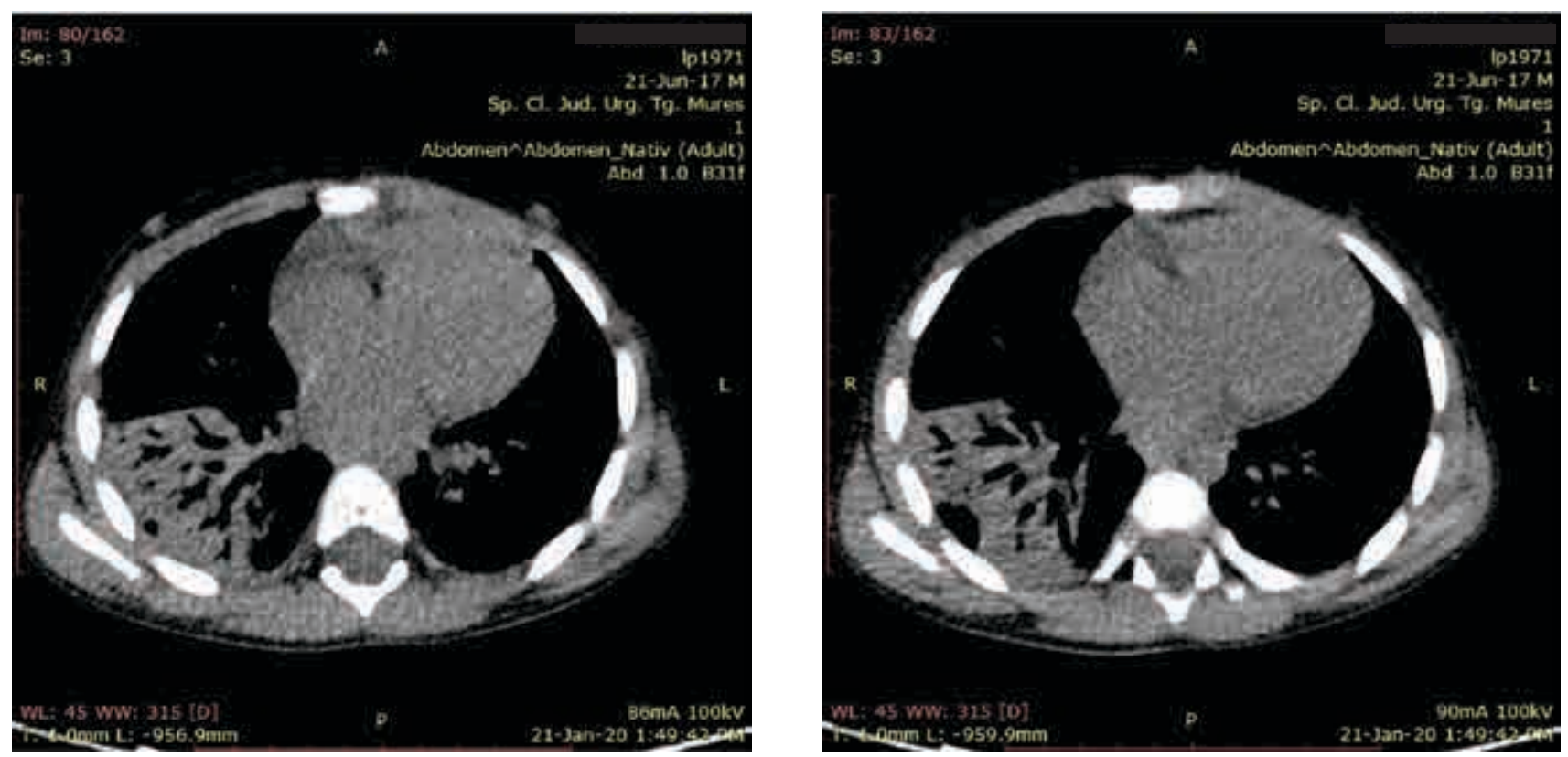

FIGURA 2. CT toracic - proces pneumonic bisegmentar în lobul inferior drept cu pneumatocele grupate subpleural, asociind în ambii plămâni arii de hiperinflație lobulară 
prevalența pe gen existentă în societatea noastră (18). În mod similar, cazul nostru a fost de sex masculin, însă patologia a fost diagnosticată mult mai repede comparativ cu vârsta medie raportată în literatură, și anume 2 ani și 6 luni. Portajul nazal pare, totuși a fi mai important la pacienții din zona temperată (19). Diseminarea hematogenă din aceste leziuni poate duce la diseminarea metastatică pe scară largă, mai ales la copiii din medii sociale precare și cu malnutriţie (20).

Implicarea pleuro-pulmonară asociată $S$. aureus reprezintă cel mai frecvent motiv de prezentare la medic $(15,17)$. Pneumonia stafilococică se prezintă în două forme: pneumonia primară datorată inoculării directe prin căile respiratorii și infecția pulmonară metastatică secundară, datorată însămânțării bacteriene din alte locuri (13,21-23). Pneumonia primară apare de obicei în copilăria timpurie și la copii care asociază şi malnutriție (13). Pacientul descris de noi a avut cel mai probabil o formă primară de pneumonie stafilococică date fiind simptomele inițiale sugestive pentru afectarea căilor aeriene superioare și lipsa identificării unui alt focar. Afectarea pleuro-pulmonară este o boală rapid progresivă şi poate avea caracteristici radiologice tipice care au o dinamică rapidă, de la o zi la alta şi anume, leziuni parenchimatoase nodulare bilaterale, multiple, condensare lobară, empiem, pneumotorax, pneumatocele şi abcese (24-26). Aşa cum este şi în cazul nostru, modificările radiologice au fost foarte importante şi sugestive pentru diagnostic, de la prima investigație radiologică care a arătat o condesare pulmonară, până la examinarea radiologică ulterioară unde s-a asociat şi pleurezie, şi la exmaminarea CT care pune în evidență şi pneumatocele.

Spitalizarea, de preferinţă într-o unitate de terapie intensivă, este indicată la pacienții cu pneumonie stafilococică pentru a face față unor urgențe potențiale şi anume, şoc septic, insuficiență respiratorie, pneumotorax tensional sau tamponadă cardiacă $(23,24)$. În

\section{BIBLIOGRAFIE}

1. Bush LM. Staphylococcus aureus infections. Available at: https:// www.msdmanuals.com/home/infections/bacterial-infections-grampositive-bacteria/staphylococcus-aureus-infections.

2. Centers for Disease Control and Prevention (CDC). Outbreaks of community-associated methicillin-resistant Staphylococcus aureus skin infections--Los Angeles County, California, 2002-2003. MMWR Morb Mortal Wkly Rep. 2003 Feb 7;52(5):88.

3. Boucher HW, Corey GR. Epidemiology of methicillin-resistant Staphylococcus aureus. Clin Infect Dis. 2008 Jun 1;46 Suppl 5:S344-9. cazul nostru, nu a fost necesară spitalizarea în secția de terapie intensivă, pacientul neprezentând criterii de şoc septic sau insuficiență respiratorie, iar stabilirea diagnosticului suficient de prompt a dus la inițierea terapiei antibiotice țintite precoce, cu impact major asupra evoluției ulterioare a cazului. Într-o analiză efectuată de către Scott şi Hall în 2009, care a inclus 509 cazuri de copii cu pneumonie şi care asociau şi malnutriție, o cauză a pneumonie a fost identificată în doar $42 \%$ dintre cazuri, hemoculturile fiind considerate o alternativă ca urmare a rezultatului pozitiv în doar 30\% din cazuri (11). Mai mult, cinci studii din această metaanaliză au utilizat aspirat pulmonar pentru izolarea agentului patogen, raportând rate de izolare care au variat între 25 şi 79\% (11). Cazul nostru susține cele menționate anterior deoarece hemocultura nu a pus în evidenta agentul patogen, dar modificările radiologice în dinamică au fost cele care ne-au orientat diagnosticul.

Identificarea agentului etiologic poate fi dificilă în cazul copiilor mici cu pneumonie acută comunitară. Pneumonia stafilococică trebuie să fie suspicionată atunci când elementele de anamneză, examenul clinic, evoluția şi aspectul radiologic în dinamică sunt sugestive pentru a institui cât mai prompt un tratament adecvat.

\section{CONCLUZII}

Pneumonia stafilococică este o patologie a copilăriei, al cărei tablou clinic este în general nespecific. Hemoculturile sunt negative în majoritatea cazurilor, iar necesitatea examenului imagistic atât la prezentare cât şi în dinamică, este esenţial pentru un diagnostic corect şi prompt. Astfel, pneumonia stafilococică este o patologie bine definită şi cunoscută în literatură, dar rămâne totuşi o patologie contemporană, impunând multiple dificultăţi legate de diagnosticul şi managementul cazurilor pediatrice.

Conflict of interest: none declared Financial support: none declared

4. Lowy FD. Staphylococcus aureus infections. N Engl J Med. 1998;20;339(8):520.

5. Barson WJ. Pneumonia in children: Inpatient treatment. Available at: https://www.uptodate.com/contents/pneumonia-in-children-inpatienttreatment/print,

6. World Health Organization. Technical bases for the WHO recommendation on the management of pneumonia in children at first level health facilities; WHO (ARI) 91.20.World Health Organization, Geneva 1991. 
7. Chickering HT, James HP Jr. Staphylococcus aureus pneumonia. JAMA. 1919;72(9):617-626.

8. Stefano A, Luis FR, Paola F et al. Global initiative for aureus pneumonia (GLIMP): an international, observational cohort study. Lancet Infect Dis. 2016;16(12):1364-1376.

9. Mandell LA, Wunderink RG, Anzueto A, Bartlett JG, Campbell GD, Dean NC, Dowell SF, File TM Jr, Musher DM, Niederman MS, Torres A, Whitney CG; Infectious Diseases Society of America; American Thoracic Society. Infectious Diseases Society of America/American Thoracic Society consensus guidelines on the management of community-acquired pneumonia in adults. Clin Infect Dis. 2007 Mar 1;44 Suppl 2(Suppl 2):S27-72.

10. Syrjälä H, Broas M, Suramo I, Ojala A, Lähde S. High-resolution computed tomography for the diagnosis of community-acquired pneumonia. Clin Infect Dis. 1998 Aug;27(2):358-63.

11. Chisti MJ, Tebruegge M, La Vincente S, Graham SM, Duke T. Pneumonia in severely malnourished children in developing countries - mortality risk, aetiology and validity of WHO clinical signs: a systematic review. Trop Med Int Health. 2009 Oct;14(10):1173-89.

12. O'Driscoll M, Crawford L, Biggar WD. Clinical features and abnormal neutrophil function in disseminated staphylococcal disease. Pediatr Infect Dis. 1985 Mar-Apr;4(2):137-41.

13. Melish ME, Campbell KA. Coagulase-positive staphylococcal infections. In: Feigin RD, Cherry JD, eds. Textbook of infectious diseases. Philadelphia: W.B. Saunders Company. 1998:1039-66.

14. Ladhani S, Konana OS, Mwarumba S et al. Bacteremia due to Staphylococcus aureus. Arch Dis Child. 2004;89:568-571.

15. Suryati BA, Watson M. Staphylococcus aureus bacteraemia in children: a 5-year retrospective review. J Paediatr Child Health. 2002;38:290-4.
16. Kabra SK, Jain YK, Kataria A et al. Disseminated staphylococcal disease. Indian Pediatr. 1996;33:683-5.

17. Hieber JP, Nelson AJ, McCracken GH Jr. Acute disseminated staphylococcal disease in childhood. Am J Dis Child. 1977; 131:181-5.

18. Singhi S, Jain V, Gupta G. Pediatric emergencies in a tertiary care hospital. J Trop Paediatr. 2003;49:207-11.

19. Von EiffC, Becker $\mathrm{K}$, Machka $\mathrm{K}$ et al. Nasal carriage as a source of Staphylococcus aureus bacteremia - Study Group. N Engl J Med. 2001;344:11-6.

20. Issac KM, Mbise RL, Hirji KF. Nosocomial bacterial infections among children with severe protein calorie malnutrition. East Afr Med J. 1992;69:433-6.

21. Chartrand SA, McCracken GHJr. Staphylococcal pneumonia in infants and children. Pediatr Infect Dis. 1982;1:19-23.

22. Naraqi S, McDonell G. Hematogenous staphylococcal pneumonia secondary to soft tissue infection. Chest. 1981;79:173-5.

23. Goel A, Bamford L, Hanslo D, et al. Primary staphylococcal pneumonia in young children: a review of 100 cases. J Trop Pediatr. 1999;45:233-6.

24. Popescu V, Dragomir D. Staphylococcal pneumonia. Pediatrie (Bucur). 1991;40:85-106.

25. Hendren WH, Haggerty RJ. Staphylococcal pneumonia in infancy and childhood: analysis of 75 cases. JAMA. 1958;168:6-16.

26. Rebhan AW, Edwards HE. Staphylococcal pneumonia: a review of 329 cases. Can Med Assoc J. 1960;82:513-7. 